\title{
Evaluasi dan Dampak Amandemen UUD 1945 Terhadap Perekonomian di Indonesia
}

\section{Dawam Rahardjo}

Indonesian Economy was built on the platform of several mainstreams of economy. Today, the constitution has a heavy task to give a paradigm that can be a guidance to the national economic. The amendments for the chapter 33 especially, can not be concluded as the birth of a new paradigm, it just throws away some ideas which used to be taken as an opportunity for many deviations, i.e., corruption, collusion, nepotism. Further question is how to bring the the new economic concept into the value market mechanism, economic efficiency, economic sustainability and social welfare.

idang Tahunan MPR baru saja selesai dan terutama menghasilkan Amandemen UUD 1945. UUD ini tidak dianggap sebagai sebuah UUD yang baru, melainkan tetap "UUD 1945", tapi yang telah mengalami perubahan dan tambahan yang pada dasarnya adalah gagasan-gagasan reformasi. Dalam pembahasan, baik di dalam maupun di luar MPR, ada beberapa gagasan besar yang ingin dimasukkan ke dalam UUD. Di bidang politik ingin ditambahkan gagasan-gagasan demokratisasi politik dan pemerintahan. Sedangkan di bidang ekonomi, muncul berbagai gagasan. Pertama mengenai gagasan liberalisasi dan marketisasi șistem perekonomian. Kedua, memasukkan konsep-konsep etika pembangunan atau etika global, seperti kebersamaan, keadilan dan pembangunan berkelanjutan (sustainable development). Ketiga, aspirasi nasionalisme ekonomi yang dicerminkan dengan istilah kemandirian ekonomi dan kesatuan ekonomi nasional. Keempat ideide mengenai kesejahteraan yang menjadi tanggungjawab negara untuk mewujudkan sejalan dengan konsep negara kesejahteraan (Welfare State).

Dalam proses diskusi mengenai amandemen, terutama dalam Panitia Ad Hoc. yang dipimpin oleh Prof. Mubyarto, terdapat dua pandangan yang bertentangan secara diametral. Pertama yang menghendaki perubahan rumusan total pada bab Kesejahteraan Sosial, khususnya pasal 33 untuk diganti dengan rumusan baru; rumusan baru itu mengarah kepada liberalisasi sistem ekonomi, khususnya meminimalkan dan memarjinalkan peranan negara di satu pihak dan diadopsinya sistem pasar yang kompetitif dan globalisasi. Sejumlah ekonomi menolak "asas kekeluargaan" yang dianggap sudah tidak relevan, untuk diganti dengan asas lain, misalnya "pasar berkeadilan" atau setidaktidaknya sistem "pasar sosial" (social market economy). Salah satu alasannya adalah bahwa asas kekeluargaan selama Orde Baru telah melahirkan KKN (Korupsi, Kronisme dan Nepotisme), karena kekeluargaan telah 
dipraktekkan sebagai "ekonomi keluarga". Kedua adalah kelompok yang menghendaki pelestarian rumusan pasal 33, walaupun menyetujui tambahan ayat-ayat yang merupakan perkembangan pemikiran baru, karena dalam kenyataannya, pasal tersebut belum mencakup, umpamanya gagasan mengenai lingkungan hidup, pembangunan yang berkelanjutan atau hak-hak dan perlindungan konsumen dan globalisasj.

Semula disangka bahwa dalam Panitia Ad Hoc. telah terjadi polarisasi ideologi, antara paham liberal dan neo-liberal dan paham sosial-demokrasi. Ternyata, yang muncul bukan paham neo-liberal, melainkan masih dapat dikategorikan dalam paham sosial-demokrat atau Negara Kesejahteraan (Welfare State). Mereka itu hanya ingin membuang gagasan yang dianggap "kuno" seperti kekeluargaan dan ingin memasukkan beberapa gagasan liberal, seperti mekanisme pasar, efisiensi ekonomi, anti monopoli, anti korupsi dan globalisasi. Karena itu perbedaannya hanyalah terletak pada, apakah pasal 33 perlu dipertahankan atau diganti dengan rumusan yang sama sekali baru.

\section{UUD 1945 Hasil Amandeman}

Dalam Pantia Ad Hoc ternyata mereka yang berpendapat ingin mengganti pasal 33 UUD 1945, lebih banyak dari yang ingin mempertahankannya, dalam perbandingan 5 banding 2. Melihat gelagat ini, maka Prof. Mubyarto menulis surat pengunduran dirinya selaku ketua maupun anggota panitia. Penggantian pasal 33 merupakan pengingkaran terhadap cita-cita proklamasi. Akan tetapi di pihak lain, ternyata terjadi arus balik untuk mendukung dipertahankannya rumusan asli pasal 33 UUD 1945. Dari hasil akhir ST MPR memang mempertahankan pasal tersebut seutuhnya, tanpa perubahan sedikitpun. Hanya saja dilakukan penamba- han pasal-pasal baru tentang ekonomi, baik pada pasal 33 maupun pada bagian lain, antara lain menjadi pasal 23B tentang "macam-macam mata uang" dan pasal 23D yang menatapkan "Negara memiliki suatu bank sentral yang susunan, kedudukan, kewenangan tanggung jawab dan independensinya diatur dengan undangundang".

Salah satu gagasan lain yang ingin dimasukkan dalam UUD adalah mengenai Bank Indonesia (yang aslinya disebut dalam Penjelasan UUD), bank sentral dan otoritas moneter yang independen dan terpisah dari dan berkedudukan sejajar dengan pemerintah. Di sinipun terjadi perdebatan, antara lain apakah nama Bank Indonesia perlu disebut ataukah cukup dengan sebutan bank sentral. Ternyata nama Bank Indonesia tidak disebut, demikian pula otoritas moneter. Yang disebut adalah bank sentral, yang mungkin saja tidak disebut dengan nama Bank Indonesia. Karena itu ada saja kemungkinan Bank Indonesia dibubarkan dan diganti dengan bank sentral atau otoritas moneter yang baru, yang ditetapkan oleh UU.

Pasal-pasal baru yang ditambahkan ada 5 ayat, yaitu 2 ayat pada pasal 33 dan 3 ayat pada pasal 34. Pada pasal 33 , ditambahkan dua ayat lagi yaitu yang berbunyi:

Ayat 4: "Perekonomian nasional diselenggarakan berdasar atas demokrasi ekonomi dengan prinsip demokrasi ekonomi dengan prinsip kebersamaan, efisiensi berkeadilan, berkelanjutan, berwawasan lingkungan, kemandirian serta dengan menjaga keseimbangan kemajuan dan kesatuan ekonomi nasional".

Ayat 1: "Ketentuan lebih lanjut mengenai pelaksanaan asal ini diatur dalam undang-undang". 
Pasal 34 ayat 1 mempertahankan ayat yang telah ada yang berbunyi "Fakir miskin dan anak-anak yang terlantar dipelihara oleh negara". Selanjutnya ada tambahan 3 ayat lagi, yaitu yang berbunyi:

Ayat 2: "Negara mengembangkan sistem jaminan sosial bagi seluruh rakyat dan memberdayakan masyarakat yang lemah dan tidak mampu sesuai dengan martabat kemanusiaan".

Ayat 3: "Negara bertanggung-jawab atas penyediaan fasilitas pelayanan kesehatan dan fasilitas pelayanan umum yang layak".

Ayat 4: "Ketentuan lebih lanjut mengenai pelaksanaan pasal ini diatur dalam undang-undang".

Dipertahankannya pasal 33, terutama ayat 2 dan 3 mempunyai arti bahwa negara masih mempunyai peranan dalam perekonomian. Di sini ada dua macam peranan negara, yaitu sebagai regulator dan sebagai aktor. Ayat 2 menekankan peranan negara sebagai aktor, yang berupa Badan Usaha Milik Negara (BUMN). Sedangkan ayat 1 , menekankan peranan koperasi, karena selama ini "usaha bersama berdasar atas asas kekeluargaan" ditafsirkan sebagai badan usaha koperasi yang diatur dengan UU tersendiri. Peranan negara sebagai regulator tidak dijelaskan dalam rumusan yang ada, kecuali jika istilah "dikuasai" diinterpretasikan sebagai "diatur", tetapi yang diatur di sini adalah sumberdaya alam yang diarahkan bagi sebesar-besar kemakmuran rakyat.

Dalam perdebatan, ayat 4 yang sekarang dimaksudkan untuk menganti pasal 33 ayat 1 . Sekarang, ayat itu merupakan tambahan guna menyesuaikan diri dengan perubahan. Sebagai rumusan pengganti ayat 1 pasal 33 , ayat ini seharusnya menekankan dipakainya asas "pasar" atau "pasar yang berkeadilan". Tapi agaknya, istilah "pasar" ditolak. Penggantinya adalah istilah "efisiensi". Tapi istilah "efisiensi" ini pun tidak dibiarkan tanpa predikat. Sebab, efisiensi saja berarti "efisiensi mikro" yang tidak bisa diterapkan pada level makro. Karena itu efisiensi makro diistilahkan dengan "efisiensi berkeadilan". Dengan demikian, mazhab Neo-Klasik tidak sepenuhnya diterima. Keterangannya adalah sebagai berikut. Jika kita menganut prinsip "efisiensi mikro", maka kita harus mengimpor beras, karena harganya beras impor lebih murah. Tapi jika impor beras dibiarkan, maka petani Indonesia akan mengalami kerugian, karena harganya merosot, akibat membanjirnya beras impor yang lebih murah. Keadaan seperti ini agaknya ditolak, sehingga walaupun harga beras internasional lebih murah, namun pemerintah harus melindungi petani Indonesia, misalnya dengan mengenakan bea masuk yang tinggi, tidak saja terhadap beras, tetapi juga komoditi yang lain, misalnya gula, hortikultura atau bahkan bahan baku tertentu untuk melindungi produsen bahan baku dalam negeri. Tapi kebijaksanaan ini akan tetap mengundang pro-kontra antara aliran yang berlawanan. Hambatan pelaksanaan "efisiensi berkeadilan" ini adalah aturan-aturan WTO dan kekuatan globalisasi.

Unsur pemikiran liberal lainnya adalah istilah "kemajuan" (progress). Tapi kemajuan inipun tidak dibiarkan tanpa penjelasan. Di sini kemajuan harus diimbangi dengan "kesatuan ekonomi nasional". Jika kemajuan hanya terjadi di daerah atau pada kelompok tertentu saja, misalnya di Jakarta atau di Jawa saja, maka kemajuan ini bersifat pincang. Karena itu kemajuan yang dikehendaki adalah kemajuan yang merata 
di seluruh Indonesia, sehingga tidak terjadi kesenjangan baik secara geografis atau sosial. Memang, kemajuan itu bisa menimbulkan kesenjangan, sebagai kecepatan perkembangan antar kelompok dan daerah itu bervariasi. Inilah tantangan untuk menciptakan kesatuan ekonomi nasional tanpa menghambat kemajuan.

Prinsip-prinsip baru yang masuk ke dalam amandemen ternyata tidak dekat dengan ide pasar, efisiensi atau globalisasi. Beberapa istilah lebih dekat dengan faham sosial demokrasi, misalnya, kebersamaan (mutuality), berkelanjutan (sustainable), berwawasan lingkungan (ecological) dan kemandirian (independent, self-relience) daripada faham ekonomi liberal. Nilai-nilaj itu muncul sebagai reaksi terhadap perkembangan ekonomi global dan perkembangan ekonomi di masa Orde Baru di Indonesia. Dalam ayat 4 itu disebut juga istilah "demokrasi ekonomi". Tapi istilah itu sudah ada dalam UUD 1945 asli, walaupun sebagai Penjelasan ayat 1 pasal 33. Istilah itu sebenarnya merupakan penjelasan terhadap apa yang dimaksud oleh usaha bersama berdasarkan asas kekeluargaan.

Prinsip-prinsip di atas sebenarnya sudah tercantum dalam TAP MPR yang ditetapkan pada masa Orde Baru dan untuk sebagian sudah dilaksanakan sebagai koreksi terhadap strategi pertumbuhan ekonomi. Sebenarnya selama Orde Baru telah terjadi dua arah perkembangan pemikiran, Di satu pihak terjadi koreksi-koreksi terhadap strategi pertumbuhan ekonomi dengan ide-ide kemandirian dan kesejahteraan. Di lain pihak terjadi pula perkembangan pemikiran ke arah liberalisasi dan globalisasi ekonomi. Masalahnya adalah bisakah keduanya bisa merupakan sintesa. Jika terjadi sintesa maka arah perkembangan pemikiran ekonomi di masa mendatang adalah mendekati konsep "the third way" yang disusun oleh Anthony
Giddens, ideolog PM Inggris dan Ketua Partai Buruh Baru, Tony Blair. Konsep jalan ketiga yang dianut oleh pemerintahan Bill Clinton, Tony Blair, Schroeder dan berbagai pemerintahan Eropa Barat lainnya itu di satu pihak pada dasarnya menyadari kegagalan sistem sosialis dan di lain pihak mengakui keunggulan sistem ekonomi pasar dan manfaat globalisasi di lain pihak, namun tetap mengacu kepada keadilan sosial dan kemakmuran yang merata, dengan peranan negara yang melakukan investasj sosial. Hanya saja pembaharuan paham sosial demokrasi ini tidak lagi menganut paham big government, tapi small but effective government. Dalam spektrum ideologi, mereka memposisikan diri sebagai kelompok tengah-kiri (left-centre).

Wacana amandemen UUD 1945, juga menyadari kegagalan sistem sosialis dengan ciri peranan kuat negara. Amandemen mengarah kepada proses demokratisasi-liberal, antara lain dengan membatasi kekuasāan presiden, meningkatkan akuntabilitas pemerintah dan hak kontrol masyarakat, khususnya lewat kontrol parlemen. Di bidang ekonomi, wacana amandemen juga mengarah pada reduksi peranan negara dan pemerintah, baik sebagai regulator maupun aktor. Sebelumnya, kecenderungan seperti itu telah terjadi, bahkan sejak akhir Orde Baru, misalnya dalam mereduksi peranan departemen koperasi dan pembinaan pengusaha kecil dan menengah, bahkan pembubaran beberapa departemen, peniadaan program kredit bersubsidi melalui Bl dan privatisasi dan bahkan pembubaran beberapa BUMN, sehingga jumlahnya berkurang, dari sekitar 440 menjadi sekitar 140 saja.

Memang dalam rangka penyehatan perbankan, banyak perusahaan swasta yang dikuasai oleh negara, sehingga praktis 
menambah jumlah BUMN. Namun, perusahaan-perusahaan yang dikuasai oleh BPPN (Badan Penyehatan Perbankan Nasional) itu langsung dijual atau didevestasi kepada swasta, termasuk swasta luar negeri. Dengan demikian dunia bisnis lebih banyak diserahkan kepada pemerintah. Sungguhpun begitu, nampak pula sejumlah "perlawanan" (resistensi). Misalnya saja, Menteri Perencanaan Pembangunan Nasional/Ketua Bappenas menentang penjualan BCA kepada asing dan menganjurkan agar bank swasta terbesar yang masih menghasilkan laba yang memadai itu, dibeli saja oleh konsorsium Jamsostek. Privatisasi Semen Padang juga ditentang keras oleh masyarakat Sumatera Barat dan karyawan BUMN tersebut.

Karena itu dapat ditarik kesimpulan, bahwa dalam spektrum ideologi, pasal-pasal ekonomi dalam UUD yang diamandemen, masih memposisikan diri di tengah-tengah (the centrist), dalam arti mengambil unsurunsur yang dapat diterima, baik dari paham kapitalis maupun sosialis. Dalam arus liberalisasi ekonomi, ternyata pandangan fundamentalisme pasar (market-fundamentalism) tidak diterima, terbukti misalnya tidak ada istilah "pasar" dalam rumusan pasal-pasal baru.

Faham negara kesejahteraan (Welfare State) ternyata dipertegas dalam tambahan pasal-pasal sosial-ekonomi, yaitu dalam pasal 34. Ayat 1 dalam pasal itu adalah peninggalan lama. Pada pasal 2 ditambahkan gagasan tentang sistem jaminan sosial (social security system), yang pada umumnya sudah melembaga di negaranegara Eropa Barat dan Amerika Utara, bahkan di banyak negara dunia ketiga. Di negara-negara tersebut, iuran jaminan sosial (social security contribution) merupakan bagian yang cukup besar dalam penerimaan negara. Dana jaminan sosial inilah yang merupakan sumber dana bagi upaya-upaya memberdayakan masyarakat yang lemah dan tidak mampu. Sistem ini juga merupakan faktor kunci terhadap terlaksananya ketentuan ayat 1 yaitu "fakir miskin dan anak-anak yang terlantar dipelihara oleh negara".

Pasal 3 mengatakan bahwa "negara bertanggung-jawab atas penyediaan fasilitas pelayanan kesehatan dan fasilitas pelayanan umum yang layak". Lagi-lagi ini adalah sepotong gagasan paham Negara Kesejahteraan yang sebenarnya sudah tercantum dalam Pembukaan UUD 1945. Ayat ini agaknya ing in mempertegas paham ini. Dalam istilah Giddens, pengertian ini tercakup dalam "negara investasi sosial" (social investment state). Di sini negara diwajibkan untuk melakukan investasi sosial, misalnya untuk menyediakan "fasilitas pelayanan kesehatan". Amartya Sen, ekonom India pemenang Hadiah Nobel untuk ekonomi tahun 1997, juga mempunyai gagasan tentang investasi sosial di bidang kesehatan ini. Dalam pandangan ini perbaikan kesehatan merupakan bagian dari peningkatan mutu sumberdaya manusia. Sedangkan sumberdaya manusia yang bermutu merupakan sumber energi pembangunan.

\section{Implikasi Bagi Bank Indonesia}

Pasal yang terutama berkaitan dengan kedudukan dan fungsi Bank Indonesia adalah pasal 23D yang berbunyi: "Negara memiliki suatu bank sentral yang susunan, kedudukan, kewenangan, tanggung jawab dan independensinya diatur dengan undangundang". UU itu sebenarnya sudah ada, yaitu UU No. 23/1999 tentang Bank Indonesia, kecuali jika UU ini akan direvisi dalam tempo dekat. UU yang baru ini berbeda secara mendasar dengan UU sebelumnya, yaitu UU No. 13/1968, dimana UU sebelum- 
nya itu juga diberi tugas pembangunan, disamping tugas pokoknya, yaitu "mengatur, menjaga dan memelihara stabilitas nilai tukar". Tugas lain itu adalah "mendorong kelancaran produksi dan pembangunan serta memperluas kesempatan kerja, guna meningkatkan taraf hidup masyarakat". Tugas lain itu pada dasarnya sama dengan tugas pemerintah, karena itu Gubernur Bank Sentral dimasukkan dalam jajaran kabinet dengan kedudukan menteri atau setaraf menteri.

Tugas itulah sebenamya yang membuat $\mathrm{Bl}$ tidak independen. Bahkan dalam Dewan Moneter, Gubernur BI adalah anggota Dewan Moneter yang ketuanya adalah Menteri Keuangan. Dalam prektek, BI dapat didikte oleh Pemerintah, bahkan Menteri Keuangan, dalam kasus Gebrakan Sumarlin, ikut melaksanakan suatu kebijaksanaan moneter yang sebenarnya termasuk tugas Bank Indonesia sebagai otoritas moneter. Dengan dibebaskannnya $\mathrm{Bl}$ dari tugas pembangunan, maka $B \mid$ sebenarnya menjadi terbebas atau independen.

Sebenarnya, sebelum keluarnya UU No. 23/199 tentang Bank Indonesia, telah ada langkah-langkah atau peristiwa menuju independensi BI. Pertama adalah keputusan Presiden Habibie yang tidak memasukkan Gubernur Bank Indonesia dalam jajaran kabinet. Kedua, adalah diberhentikannya kewajiban Bl untuk memberikan KLBI (Kredit Likuiditas Bank Indonesia), kecuali untuk beberapa program. Ketiga adalah penolakan "perintah " Presiden Abdurrahman Wahid kepada Dr. Syahril Sabirin untuk mundur dari jabatannya sebelum masa jabatannya berakhir. Sampai Abdurrahman Wahid sendiri turun dari jabatan kepresidenan melalui impeachment MPR, sementara Dr. Syahrir Sabirin tetap sebagai Gubernur $\mathrm{BI}$ hingga masa jabatannya selesai.
Konsep independensi bank sentral adalah salah satu gagasan reformasi ekonomi yang mengikuti liberalisme. Pada masa Orde Baru, peranan negara sangat, yaitu menurut rumusan Giddens "negara mendominasi masyarakat sipil" yang dalam perekonomian, negara melakukan intervensi terhadap pasar, sehingga menimbulkan distorsi. Dalam perkembangan ke arah liberalisasi, peranan intervensi negara terhadap pasar dikurangi secara drastis. Tapi sebagai gantinya, peranan bank sentral ditingkatkan dalam arti tertentu. Di masa lalu, negara melalui pemerintah melakukan intervensi terhadap pasar secara langsung. Dalam perkembangan baru, negara masih bisa melakukan intervensi, tetapi secara tidak langsung. Intervensi tidak langsung itu, tidak berwujud kebijaksanaan fiskal melainkan kebijaksanaan moneter. Sedang yang diserahi tugas melakukan kebijaksanaan moneter adalah bank sentral, dalam hal ini BI. Dalam teori ekonomi, kebijaksanaan fiskalis Keynesian, digantikan dengan kebijaksanaan moneter yang Friedmanian, dengan kepercayaan (berdasarkan teori), bahkan kebijaksanaan moneter, misalnya pengendalian volume uang beredar atau pemetapan suku bunga, dapat mempengaruhi pertumbuhan ekonomi dan kesempatan kerja.

Agar bisa melaksanakan tugas menyelenggarakan kebijaksanaan moneter yang efektif, bank sentral perlu diberi status yang independen, terutama dari pemerintah. Sasaran dari kebijaksanan moneter adalah, terutama mengendalikan inflasi dan menjaga stabilitas nilai mata uang rupiah. Namun masalahnya adalah, apakah bank sentral atau otoritas moneter sendirian, walaupun independen dapat melaksanakan tugas itu. Sebab sumber inflasi umpamanya, tidak semua dapat dikontrol oleh bank sentral. Inflasi bisa terjadi 
karena bencana kekeringan dan gagal panen, kenaikan harga BBM dan tarif listrik atau kenaikan gaji pegawai yang kesemuanya ditetapkan oleh pemerintah atau bahkan tergantung pada alam. Jadi ada pendapat yang mengatakan bahwa tugas mengendalikan inflasi terlalu besar untuk dibebankan kepada bank sentral saja. Stabilitas mata uang juga dipengaruhi oleh APBN yang antara lain memogramkan bantuan luar negeri. Jika upaya pemerintah untuk memasukkan devisa dari kredit luar negeri itu, maka nilai rupiah bisa jatuh. Masalah keamanan juga bisa menyebabkan jatuhnya nilai rupiah, padahal masalah itu di luar jangkauan bank sentral. Karena itu bank sentral harus bekerja sama dengan pemerintah. Namun, hal ini tidak berarti mengurangi independensi bank Indonesia. Jika tidak ada koordinasi maka bisa terjadi saling tuding antara pemerintah dan otoritas moneter. 